\title{
Study of Electrolytes in Serum and Aqueous Humour in Cataract Patients - Comparative Study
}

\author{
Neela Mannangi ${ }^{1}$, Mahantesh Bhutal ${ }^{2}$, Shubhajayarm ${ }^{3}$, Dr. Jayashree M P ${ }^{2}$ \\ ${ }^{1}$ Asso Professor at SNMC \& HSK BAgalkot Dept of Biochemistry \\ ${ }^{2}$ Assistant Professor at SNMC \& HSK BAgalkot Dept of Biochemistry \\ ${ }^{3}$ Professor at MMC \& RI, Mysore
}

DOI: $10.36348 /$ sijb.2020.v03i03.001

| Received: 02.03.2020 | Accepted: 09.03.2020 | Published: 16.03.2020

*Corresponding author: Dr. Jayashree M P

\section{Abstract}

In India, cataract accounts for $80 \%$ of treatable blindness. Many factors such as ageing, altered blood electrolyte levels, diabetes mellitus, hypertension, nutrition and family history are involved in cataract genesis. Lens has a high content of potassium and low content of sodium. These two cations are in balance with each other due to Na+- K+-ATPase pump and lens capsular permeability. Normally to maintain lens membrane permeability, water electrolyte balance must be maintained intracellularly as well as extracellurly. Hence alteration in cation concentration of aqueous humors can be attributed to changes in the serum electrolytes, these ultimately affect lens metabolism leading to cataract formation. The composition of aqueous humour has been studied in various animals. Few human aqueous humour studies were conducted so far. An attempt is made here to establish a range for the electrolytes mentioned i.e. sodium, potassium, and chloride in the human aqueous humour in cataract patients and also compare it with serum electrolyte levels. It's a case control study. Sample size includes 60. Aqueous humour and serum electrolytes $\left(\mathrm{Na}^{+}, \mathrm{K}^{+}, \mathrm{Cl}^{-}\right)$were estimated by ion selective electrode method. Sodium and Chloride levels were higher in serum compared to aqueous humour. Further sodium levels were increased from Grade I to Grade IV cataract. Biochemical parameters such as serum electrolytes can be used as marker to determine the risk involved in progression of cataract. This serum electrolytes measurement should be done as a routine screening investigation as it might help in predicting early development of senile cataract.

Keywords: Electrolytes, serum, Aqueous humour, cataract.

Copyright @ 2020: This is an open-access article distributed under the terms of the Creative Commons Attribution license which permits unrestricted use, distribution, and reproduction in any medium for non-commercial use (NonCommercial, or CC-BY-NC) provided the original author and source are credited.

\section{INTRODUCTION}

In India, cataract accounts for $80 \%$ of treatable blindness [1]. Many factors such as ageing, altered blood electrolyte levels, diabetes mellitus, hypertension, nutrition and family history are involved in cataract genesis. Lens has a high content of potassium and low content of sodium. These two cations are in balance with each other due to Na+- K+-ATPase pump and lens capsular permeability. The permeability of chloride is high in the lens. The Na+- $\mathrm{K}+-2 \mathrm{Cl}-$ co-transporter has been identified by the dependence of cation flow on anion concentration. A disturbance in the chloride concentration or chloride handling by the lens will jeopardize the ability of the lens to maintain its hydrated state and threaten a loss of osmotic equilibrium that may result in cataract [2]. Normally to maintain lens membrane permeability, water electrolyte balance must be maintained intracellularly as well as extracellurly. Membrane permeability is shown to be responsible for maintenance of lens transparency.
Sodium is major serum extracellular cation while potassium is major intracellular cation. In lens, the concentration of sodium is less than potassium while in serum it is vice versa. This cation balance maintains osmotic pressure and thus water balance across the lens membrane by the action of NaKATPase [3]. Mansour Mirsamadi, Issa, et al. in 2004 have shown that changes in serum electrolytes levels can induce changes in aqueous humor electrolytes levels of lens and probably cataract formation. Hence alteration in cation concentration of aqueous humors can be attributed to changes in the serum electrolytes, these ultimately affect lens metabolism leading to cataract formation [4]. So any cause that alter the sodium level in serum will directly affect its elevation in aqueous humor fluid which may alter lens membrane permeability and resulting in osmotic imbalance. These further results in development and progression of cataract. 
The composition of aqueous humour has been studied in various animals. But very few human aqueous humour studies are conducted so far. So in this study we made an attempt to establish a range for the electrolytes i.e. sodium, potassium, and chloride in the human aqueous humour and also in serum of cataract patients.

\section{OBJECTIVES}

- To estimate electrolytes like $\mathrm{Na}^{+}, \mathrm{K}^{+}, \mathrm{Cl}^{-}$in serum and aqueous humour in cataract patients.

- To compare these electrolyte levels between serum and aqueous humour.

- Correlate the serum and aqueous electrolyte levels with different grades of cataract.

\section{MATERIAL AND METHODOLOGY}

The study was conducted between Januarys July 2017 at SNMC \& HSK Hospital Bagalkot. It's a case control study. Sample size includes 60. Sample size was calculated according to the study done by Reepa Borah Choudhury et al. [5]

Informed written consent was taken from all the selected cataract patients. Ethical clearance was approved by institutional ethical committee. Patients with history of hypertension, diabetes, cardiovascular diseases, liver diseases, renal diseases, trauma, metabolic diseases, radiation therapy and h/o taking drugs were excluded from the study.

$2 \mathrm{ml}$ of venous blood for serum was collected in a plain tube. Around $0.3 \mathrm{ml}$ of aqueous humor was collected intraoperatively in a tuberculin syringe under aseptic precautions guided by ophthalmologist. Aqueous humor and serum electrolytes $\left(\mathrm{Na}^{+}, \mathrm{K}^{+}, \mathrm{Cl}^{-}\right)$ were estimated by ion selective electrode method. Slit lamp examination was done to assess the grades of cataract. Results were expressed in Mean \pm S.D using SPSS 11 version. Student' $t$ ' test \& ANOVA was used to compare between serum and aqueous electrolytes in different grades of cataract. $\mathrm{P}<0.05$ as significant is considered.

\section{RESULTS}

Table-1: Age \& Gender distribution of patients

\begin{tabular}{|l|l|l|l|}
\hline Age (yrs) & Male (\%) & Female (\%) & Total (\%) \\
\hline $45-50$ & $0(0.0)$ & $1(100.0)$ & $1(100.0)$ \\
\hline $51-55$ & $7(50.0)$ & $7(50.0)$ & $14(100.0)$ \\
\hline $56-60$ & $10(55.6)$ & $8(44.4)$ & $18(100.0)$ \\
\hline $61-65$ & $8(47.1)$ & $9(52.9)$ & $17(100.0)$ \\
\hline $66-70$ & $7(77.8)$ & $2(22.2)$ & $9(100.0)$ \\
\hline $71+$ & $1(50.0)$ & $1(50.0)$ & $2(100.0)$ \\
\hline Total & $33(54.1)$ & $28(45.9)$ & $61(100.0)$ \\
\hline
\end{tabular}

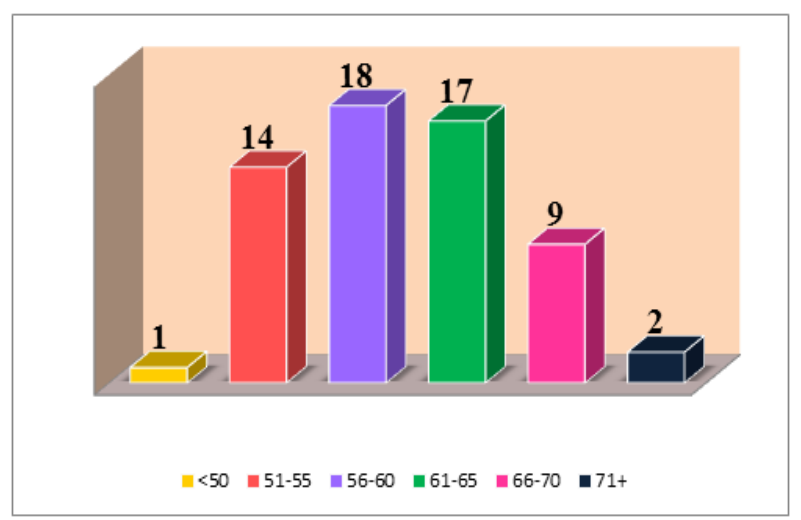

Fig-1: Shows distribution of patients of different age groups

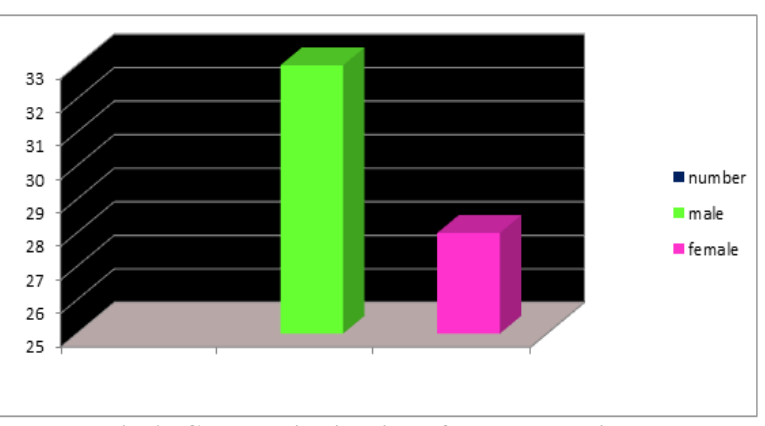

Fig-2: Gender distribution of cataract patients

Table-2: Comparison of electrolytes between aqueous humour and serum in cataract patients

\begin{tabular}{|l|l|l|l|l|}
\hline Electrolytes & Aqueous humour & Serum & t & p \\
\hline $\mathrm{Na}+(\mathrm{meq} / \mathrm{lt})$ & $142.80 \pm 8.39$ & $139.16 \pm 5.16$ & 2.884 & $.005^{* *}$ \\
\hline $\mathrm{K}^{+}$(meq/lt) & $3.81 \pm 0.56$ & $4.07 \pm 0.66$ & -2.360 & $.020^{*}$ \\
\hline $\mathrm{Cl}^{-}$(meq/lt) & $103.68 \pm 4.75$ & $102.40 \pm 3.79$ & -.926 & .356 \\
\hline
\end{tabular}

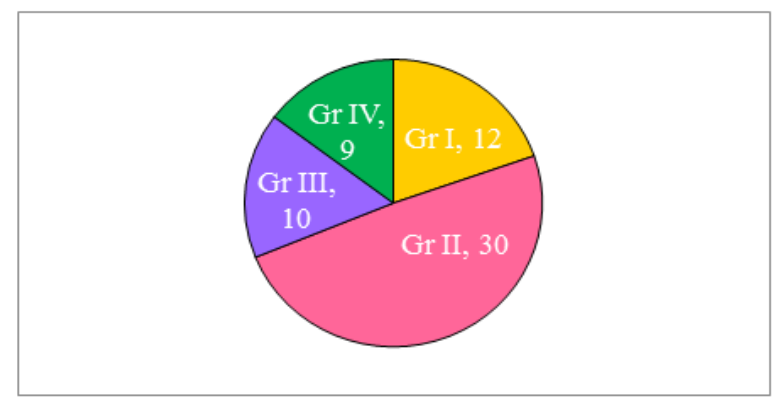

Fig-3: Number of patients in different grades of cataract 
Table-3: Comparison of altered aqueous humour and serum electrolytes in different grades of cataract

\begin{tabular}{|c|c|c|c|c|c|c|}
\hline Grades (No.) & \multicolumn{3}{|c|}{ Aqueous Humour } & \multicolumn{3}{|l|}{ Serum } \\
\hline & $\mathrm{Na}$ & $\mathrm{K}$ & $\mathrm{Cl}$ & $\mathrm{Na}$ & $\mathrm{K}$ & $\mathrm{Cl}$ \\
\hline Gr- I (12) & $141.0 \pm 5.7$ & $3.9 \pm 0.72$ & $102.58 \pm 4.03$ & $135.25 \pm 5.62$ & $3.91 \pm 0.33$ & $102.16 \pm 2.72$ \\
\hline Gr- II (30) & $146.13 \pm 6.7$ & $3.6 \pm 0.53$ & $103.13 \pm 5.10$ & $138.60 \pm 5.62$ & $4.29 \pm 0.90$ & $102.66 \pm 4.02$ \\
\hline Gr- III (10) & $146.70 \pm 6.2$ & $3.5 \pm 0.65$ & $103.10 \pm 5.10$ & $139.10 \pm 3.84$ & $4.7 \pm 0.62$ & $103.20 \pm 3.55$ \\
\hline Gr- IV (9) & $154.75 \pm 7.38$ & $3.4 \pm 0.29$ & $104.62 \pm 4.43$ & $140.37 \pm 7.98$ & $5.10 \pm 0.67$ & $103.25 \pm 3.80$ \\
\hline $\mathrm{F}$ & 6.60 & 2.32 & 0.85 & 0.28 & 0.75 & 0.69 \\
\hline $\mathrm{p}$ & $0.001 * *$ & 0.08 & 0.46 & 0.083 & $0.05 *$ & 0.56 \\
\hline
\end{tabular}

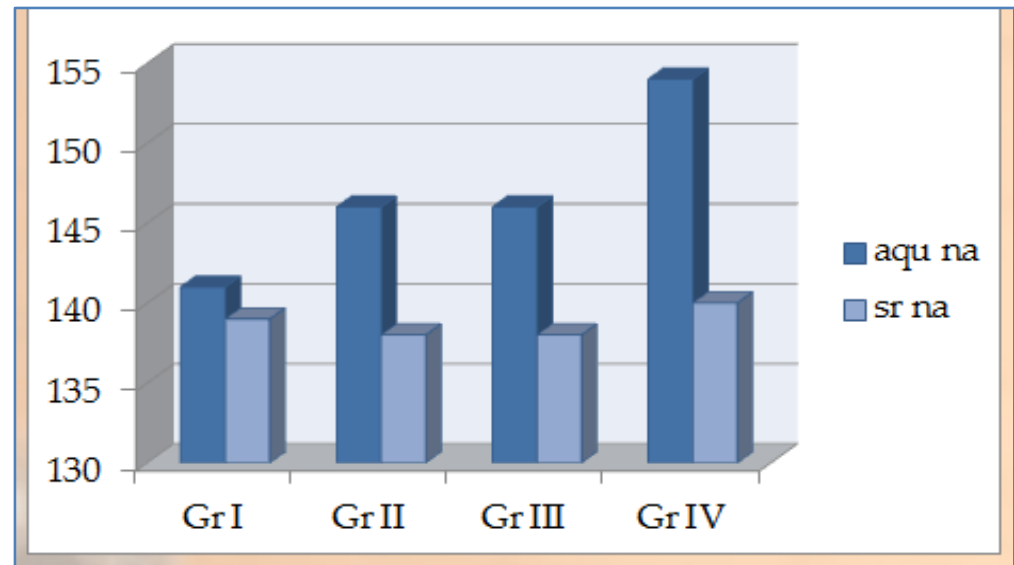

Fig-4: Comparision of altered serum and aqueous $\mathrm{Na}^{+}$levels in different grades of cataract

\section{DISCUSSION}

Any opacification in the lens is called cataract. Cataract is the most common blindness in the world. Many factors such as physical, chemical or biological which disturbs the critical intra and extracellular equilibrium of water and electrolytes or destroys the colloid system of the lens fibres tends to bring about opacification. Aqueous humour is a clear fluid secreted by the ciliary epithelium from the serum in the eye. Lens lies in close apposition with that of aqueous humour and derives its nutrition from this aqueous humour. Hence, any electrolyte imbalance in the serum can lead to changes in aqueous humour electrolytes which can affect the lens metabolism leading to cataract formation [6]. Mansour Mirsamadi, Issa, et al. in 2004 have shown that changes in serum electrolytes levels can induce changes in aqueous humor electrolytes levels of lens and probably cataract formation [4]. Multiple factors such as UV light exposure, diet, some metabolic disorders, quality of life, and cationic pump malfunction and lens metabolism disorders are believed to have a role in cataract formation [7]. In this study there was increased $\mathrm{Na}$ level in different grades of cataract patients and may progress for the cataract disorder. This is because higher level of serum $\mathrm{Na}$ might make it more difficult for sodium pumps to maintain the low level of intracellular $\mathrm{Na}$ which is required for lens transparency. Normally lens has high content of potassium (125 meq/ lt) and low Na (14-26 $\mathrm{meq} / \mathrm{lt})$. These two cations are in balance with each other, which is due to action of NaK ATPase pump which [8]. Since lens metabolism is associated with aqueous humor and this thin fluid itself is produced from blood secretions, serum electrolytes concentration may directly affect electrolytes of aqueous humor fluid and in turn lens metabolism [9]. It may then be inferred that continuous sodium-pump-mediated sodium extrusion is imperative in the maintenance of ionic homeostatic balance in the eye fluid. It may equally be stated that without this active sodium extrusion, sodium and calcium ion content in the fluid may increase resulting in lens swelling and deterioration of transparency [10]. In our study we also observed that aqueous potassium levels were lower compared to serum electrolyte levels in cataract patients. But in some studies aqueous levels of potassium in cataract patients were raised (in 50\% of cases) when compared to normal aqueous levels. However, since most of the electrolyte levels in serum and aqueous humour were not altered when compared to normal values, it was difficult to establish a correlation between electrolyte levels and the type of cataract [11]. There is a significant difference between serum and aqueous humour electrolyte levels in normal cataract patients. Aqueous sodium levels as compared to serum sodium levels were higher in patients with cataract. However, from the practical point of view, we could study the electrolyte levels only in cataract patients visiting our hospital and not in the normal individuals [12] Mansour et al. also failed to detect any significant difference in serum K+ levels. Donnelly in an Edinburg-based study on 1000 patients of senile cataract found a significantly higher serum $\mathrm{Na}+$ in cataract cases $(P=0.03$; OR $=$ 1.04; 95\% CI: 1.0-1.08) [13]. Similar to our study, they also did not find any difference of serum $\mathrm{K}+(P=0.67$; $\mathrm{OR}=1.05 ; 95 \% \mathrm{CI}$ : 0.98-1.12). Miglior et al . conducted a case-control study in Italy to evaluate risk factors for nuclear, cortical, posterior subcapsular and mixed 
cataract [14]. The study group (age range: 40-75 years) comprised 385 cases and 215 controls. They classified serum $\mathrm{Na}+$ levels (in $\mathrm{mEq} / \mathrm{L}$ ) into: 138.1-141, 141.1$143,>143$. They reported a significantly higher risk of the first (OR 3.1;95\% CI: 1.41 to 6.59 ) and the third group (OR 2.14: 95\%CI: 1.07 to 4.29), with CC only (defined by LOCS II), but no significant association of the central group (OR 1.47: 95\%CI: 0.67 to 3.24) with $\mathrm{CC}$ and with other cataract subgroups. In a similar fashion, they also reported the higher serum $\mathrm{K}+(\mathrm{OR}$ 4.27; 95\%CI: 2.21 to 10.7 ). Understandably they appear puzzled and suggest that the association may be spurious [12].

\section{CONCLUSION}

Biochemical parameters such as serum electrolytes i.e. Sodium level can be used as marker to determine the risk involved in progression of cataract. As there is less research on human aqueous humour, further research scope is required to establish the normal range of electrolytes present in the aqueous humour of the normal individuals and compare it with that of the disease state. From a clinical perspective, it can be suggested that after 50 years of age, serum electrolytes measurement should be done as a routine screening investigation which may help in predicting and preventing early development of senile cataract.

\section{REFERENCES}

1. Jadav Prashantkumar, M., Sharma Hariom, M., Maniar Megha, A., Chaudhary Nitinkumar, G., Maheshwari Amit, V., \& Javia, H. Relationship between altered level of serum electrolytes and risk of senile cortical cataract-A Case Control Study.

2. Zhang, J. J., \& Jacob, T. J. (1997). The role of chloride in the lens of the eye. Experimental Physiology: Translation and Integration, 82(2), 245-259.

3. Seddon, J., Fong, D., West, S. K., \& Valmadrid, C. T. (1995). Epidemiology of risk factors for agerelated cataract. Survey of ophthalmology, 39(4), 323-334.

4. Mirsamadi, M., Nourmohammadi, I., \& Imamian, M. (2004). Comparative study of serum $\mathrm{Na}+$ and
$\mathrm{K}+$ levels in senile cataract patients and normal individuals. International journal of medical sciences, 1(3), 165.

5. Deka ${ }^{4}$, D. C. Comparative Study Of Serum And Aqueous Humour Electrolytes In Diabetic And Non-Diabetic Cataract Patients.

6. Seddon, J., Fong, D., West, S. K., \& Valmadrid, C. T. (1995). Epidemiology of risk factors for agerelated cataract. Survey of ophthalmology, 39(4), 323-334.

7. Van Heyningaen, R. (1961). The Lens metabolism and cataract. In (ed) Davson H.

8. Donnelly, C. A., Seth, J., Clayton, R. M., Phillips, C. I., Cuthbert, J., \& Prescott, R. J. (1995). Some blood plasma constituents correlate with human cataract. British journal of ophthalmology, 79(11), 1036-1041.

9. Morris Jr, R. C., Schmidlin, O., Frassetto, L. A., \& Sebastian, A. (2006). Relationship and interaction between sodium and potassium. Journal of the American College of Nutrition, 25(sup3), 262S$270 \mathrm{~S}$

10. Luntz, M.H.(2000). Clinical types of cataract. In: Tasman W, Jeager A ed. Duane's. Clinical Ophthalmology. Philadelphia:Lipincott-Raven Publishers; 5-7.

11. Beebe, D. (2003). The lens. In: Kaufman P L, Adler F H Eds. Adler's Physiology of the Eye, Clinical Application.10thed. St. Louis: Mosby: 117-158.

12. Donnelly, C. A., Seth, J., Clayton, R. M., Phillips, C. I., Cuthbert, J., \& Prescott, R. J. (1995). Some blood plasma constituents correlate with human cataract. British journal of ophthalmology, 79(11), 1036-1041.

13. Miglior, S., Marighi, P. E., Musicco, M., Balestreri, C., Nicolosi, A., \& Orzalesi, N. (1994). Risk factors for cortical, nuclear, posterior subcapsular and mixed cataract: a case-control study. Ophthalmic epidemiology, 1(2), 93-105.

14. Chylack, L. T., Leske, M. C., McCarthy, D., Khu, P., Kashiwagi, T., \& Sperduto, R. (1989). Lens opacities classification system II (LOCS II). Archives of ophthalmology, 107(7), 991-997. 